\title{
The taxonomic implication of leaf anatomy in tribe Sorbarieae (Spiraeoideae: Rosaceae)
}

\author{
Jun-Ho Song and Suk-Pyo Hong* \\ Laboratory of Plant Systematics, Department of Biology \& Research Institute for Basic Sciences, \\ Kyung Hee University, Seoul, 130-701, Korea \\ (Received 13 May 2014; Accepted 28 May 2014)
}

\section{쉬땅나무족(Sorbarieae Rydb., 장미과) 잎의 해부학적 형질 및 분류학적 유용성}

\author{
송준호 · 홍석표* \\ 경희대학교 이과대학 생물학과 및 기초과학연구소
}

\begin{abstract}
A comparative study of leaf anatomy in tribe Sorbarieae (Adenostoma, Chamaebatiaria, Sorbaria, Spiraeanthus) including one related genus Lyonothamnus was carried out using light microscopy. Anatomical characteristics of the leaf blade and midrib were described and taxonomically evaluated. The anatomical characters which described in this study are as follows: thickness of leaf midrib, blade in cross section, cuticle, epidermal cell, stoma, trichome, mesophyll, crystal, main vasculature type. All features were compared and the vascular patterns of midrib were distinguished two types. - Type 1: Trace tripartite (Adenostoma), Type 2: Trace continuous, subtype 2A: flat arc (Chamaebatiaria, Spiraeanthus), subtype 2B: U-shape arc (Lyonothamnus, Sorbaria). In conclusion, some of leaf anatomical characters (e.g., cuticle, epidermal cell, trichome, mesophyll, main vasculature type) can be useful for diagnostic features. Hypostomatic type, dorsiventral mesophyll, Ushape vasculature type would constitute a major characters for genus Sorbaria in Sorbarieae. The detailed anatomical description of studied taxa is provided, and its systematic importance is also briefly discussed.
\end{abstract}

Keywords: Vascular bundle, Leaf anatomy, Sorbaria, Sorbarieae, Rosaceae

적 요: 쉬땅나무족(Adenostoma: 2spp., Chamaebatiaria: 1sp., Sorbaria: 9spp., Spiraeanthus: 1sp.)과 근연분류군인 Lyonothamnus 속 2 종을 포함한 총 15 분류군의 잎의 해부학적인 형질을 광학현미경(LM)을 이용하여 연구하였다. 모든 해부학적 형질은 잎의 횡단면을 비교하고 기재하였으며, 해부학적 형질로 분류군 간 중륵과 엽신의 횡단 면, 중륵의 두께, 각피층, 표피세포, 기공, 모용, 엽육조직, 결정체, 주유관속 유형 등의 형질을 비교하였다. 본 연 구 결과에서는 중륵의 주유관속 패턴을 크게 두 타입으로 구분하여 기재하였다. Type 1: 불연속유관속, 독립된 3개의 호형(Adenostoma), Type 2: 연속유관속, subtype 2A: 다소 편평(flat)한 호형(Chamaebatiaria, Spiraeanthus), subtype 2B: U-shape 호형(Lyonothamnus, Sorbaria). 또한 세부적인 해부학적 형질에 대해 자세히 기재하였고, 분 류학적 중요성에 대해 논의하였다. 결론적으로, 일부 잎의 해부학적 형질(예, 각피층, 표피세포, 모용, 엽육조직, 유관속 패턴)은 진단형질로서 유용함을 확인하였고, 쉬땅나무족 내 이면기공엽과 배복성의 엽육조직, U-shape의 유관속 패턴의 형질이 쉬땅나무속을 구분하는 주요형질임을 밝혔다.

주요어: 유관속, 잎 해부, 쉬땅나무속, 쉬땅나무족, 장미과

\footnotetext{
*Author for correspondence: sphong@khu.ac.kr
}

http://www.pltaxa.or.kr

Copyright (C) 2014 the Korean Society of Plant Taxonomists 
쉬땅나무족(tribe Sorbarieae Rydb.)은 장미과(family Rosaceae Juss.)내의 조팝나무아과(subfamily Spiraeoideae Arn.)에 속하는 분류군으로, 최근 장미과의 분류체계에 따 르면 4개 속(Adenostoma Hook. \& Arn., Chamaebatiaria Maxim., Sorbaria A. Braun, Spiraeanthus Maxim.)을 포함하 고 있으며, 주로 북반구의 온대지역, 중앙아시아, 동아시 아, 서부아메리카 등지에 분포하는 것으로 알려져 있다 (Potter et al., 2007).

쉬땅나무족은 관목 또는 다년생 초본으로, 전열의 우상 복엽이 호생하고, 화서는 원추 또는 취산화서로, 화탁은 반구형, 종형, 또는 튜브형이다. 대략 10-50개의 수술이 나 타나며, 암술은 일반적으로 5 개로 나누어져 있다. 꽃받침 은 대생으로 배열하고, 배주는 존재하나 드물다. 특히 심 피가 꽃받침과 대생하고 숙존성인 탁엽이 존재하는 특징 으로 아과 내 근연인 국수나무족(Neillieae), 조팝나무족 (Spiraeeae)과 구분된다(Rydberg, 1908).

최근 Potter et al. (2007)의 장미과 분자계통학적 연구에 따르면, 배주 수와 배주형, 골돌과의 형질로 Schulze-Menz (1964)에 의해 쉬땅나무족 내 분류군으로 인식되어 온 Lyonothamnus 속이 조팝나무아과 내에서 정확한 족 내 분 류학적 위치를 찾지 못하고 있는 것으로 나타났고, 많은 학자들(Rydberg, 1908; Hutchinson, 1964; Schulze-Menz, 1964; Takhtajan, 2009)에 의해 수과의 열매를 갖는 특징으 로 독립된 Adenostomeae족으로 인식되었던 Adenostoma속 이 쉬땅나무족에 포함되어, 장미과 내 다른 분류군들과는 구별되는 독립된 족임을 지지하였다. 그러나 아직까지 족 간, 족내 뚜렷한 형태학적, 미세형태학적, 또는 해부학적 공유파생형질이 밝혀지지 않은 상태이다.

족 내 가장 큰 분류군인 Sorbaria속은 전 세계적으로는 약 10 여 종이 분포하는 것으로 알려져 있으며, 국내에는 좀쉬 땅나무(Sorbaria kirilowii (Regel \& Tiling) Maxim.), 쉬땅나무 (S. sorbifolia (L.) A. Braun var. stellipila Maxim.), 청쉬땅나무 (S. sorbifolia (L.) A. Braun f. incerta C. K. Schneid.)가 분포하 는 것으로 알려져 있다(Lee, 2007; Song et al., 2010). Rahn (1989)은 표본 조사를 통한 Sorbaria속의 분류학적 연구에 서 골돌과의 크기와 털의 유무, 꽃받침의 형태, 수술의 개 수 등과 같은 특징으로 S. sorbifolia, S. grandiflora, S. kirilowii, S. tomentosa, S. tomentosa var. angustifolia 4종 1변종으로 분류 군들을 인식하였다. 하지만 외부형태적인 형질 이외에 다 른 형질에 대한 관찰 및 고찰이 없어 추가적인 다양한 분류 학적 형질(화분학, 미세형태학, 해부학, 분자계통학)을 통 한 본 분류체계의 재검토가 필요하다(Song in prep.).

해부학적인 형질은 현화식물의 분류군에 있어 분류학 적 위치와 유연관계 뿐 아니라 종 동정을 위해 이용되고 있다(Solereder, 1908; Metcalfe and Chalk, 1950, 1979; Agbaywa and Noukwu, 2004; Kharazian, 2007; Stuessy, 2008). 잎의 해부학적 형질 또한 최근까지도 다양한 분류군에서 연구되고 있으며, 그 분류학적 유용성이 검토되고 있다
(Gonçalves and Rodriigo, 2003; Noorbakhsh et al., 2008; Araújo et al., 2010; De Villiers et al., 2010; Millán and Kahn, 2010; Moraes et al., 2011; Almeida et al., 2013). 장미과에 대 한 해부학적 연구로는 Lee et al. (2010)이 한국산 조팝나무 속의 엽병 해부를 통해 진단형질로써의 가치를 검토하고, 검색표를 제시한 바 있다. 반면, 쉬땅나무족의 해부학적 형질에 관한 연구로는 목부의 해부(wood anatomy)로만 제 한적으로 시도되었고(Zhang, 1992; Zhang et al., 1992), 잎의 해부학적 연구는 전무한 상태이다.

따라서, 본 연구의 주요 목적은 쉬땅나무족 잎의 다양한 해부학적 형질들(엽신의 두께, 각피층, 기공, 모용, 중륵 단면의 모양, 중륵 유관속 형질, 결정체 등)을 광학현미경 $(\mathrm{LM})$ 을 통해 자세히 관찰하고 기재하며, 본 연구 결과로 부터 얻어지는 해부학적 형질들을 근거로 분류군 사이에 진단형질로서의 적용 가능성을 검토하는데 있다. 또한, 해부학적 형질과 서식지 내 환경요인과의 연관성을 간단 히 고찰하고자 하였다.

\section{재료 및 방법}

본 연구에 사용된 Adenostoma속 2종, Chamaebatiaria속 1 종, Lyonothamnus속 1종, 1아종, Sorbaria속 6종, 2변종, 1품 종, Spiraeanthus속 1종의 잎 재료를 표본관(A, C, GH, K, KH, KHUS, MO, PE, SNUA, Holmgren and Holmgren, 1998)으로 부터 대여한 석엽표본에서 확보하였고, 일부 분류군들은 직접 야외 채집하여 FAA ( $40 \%$ formalin: $40 \%$ glacial acetic acid: $70 \%$ ethyl alcohol) mixture에 고정한 후, $70 \%$ alcohol에 장기 보관하면서 관찰하였다. 이미 건조된 표본이나, 대출 표본으로부터의 재료는 약 $90^{\circ} \mathrm{C}$ 에서 3 분간 끓이거나 연화 제(water: agepon solution $=20: 1$ )에 넣어, 24시간 이상 담가 조직을 부드럽게 한 후, $70 \%$ alcohol에 보관하여 실험에 사 용하였다. 사용된 재료는 Appendix에 제시하였다.

쉬땅나무족 내 분류군의 다양한 잎의 형태를 고려하여, 대상 분류군의 잎과 소엽을 관찰하였다. 침엽과 유사한 형태를 나타내는 Adenostoma속의 경우, 잎의 가운데 부분 횡단면을 관찰하였고, 복엽을 나타내는 나머지 분류군의 경우, 중앙부 소엽(middle leaflet)의 가운데 부분을 절단하 여 관찰하였다. 또한 서식환경에 따른 변이를 고려해 가 능한 분류군 당 최소 2 개체 이상, 10 개 이상의 절편을 이용 하여 관찰하였다.

잎의 해부학적인 구조를 밝히기 위해서 파라핀 매몰법 을 사용하였다(Ruzin, 1999; Song et al., 2012). 자동조직처 리기(automatic tissue processor; Shandon Citadel 2000, Thermo Shandon, Pittsburgh, PA, USA)를 이용하여 TBA (tert Butyl-alchohol series)로 탈수하고, 녹는점이 $56-58^{\circ} \mathrm{C}$ 인 파라핀과 치환시켜 조직포매기(tissue embedding system; Shandon Histocentre 3, Thermo Shandon, Pittsburgh, PA, USA)로 embedding cassettes에 매몰한 후 조직절편기 
(manual rotary microtome; Shandon Finesse E, Thermo Electron, Pittsburgh, PA, USA)를 이용하여 8-10 $\mu \mathrm{m}$ 두께로 절단하였다. 절단된 절편을 $40^{\circ} \mathrm{C}$ 의 물위에 floating 시킨 후 슬라이드 글라스(slide glass) 위에 부착시켜 신전기(slide warmer; J-HSW, JISICO, Seoul, Korea)에 올려 신장시키고 완전 건조시켰다. 준비된 슬라이드를 자동염색장치 (automatic slide stainer; Varistain 24-4, Thermo Shandon, Pittsburgh, PA, USA)를 이용하여 Safranin O와 Fastgreen $\mathrm{FCF}$ 로 이중 염색하고, entellan으로 봉입하였다. 영구표본 은 광학현미경(light microscopy; BX-41 Laboratory Microscope, Olympus America, Melville, NY, USA)하에서 관찰하 고 현미경용 디지털카메라(digital camera for microscopes; MDX-30, Shinwoo Optics, Anyang, Korea)로 촬영하였다. 유 관속의 층수 $(\mathrm{NVL})$, 배축면의 길이(VA), 중심축 유관속 길 이(DVA) 및 너비(WMV)간의 관계를 나타내기 위해 피어 슨 상관관계(Pearson correlation)를 이용하여 분석하였다
(IBM SPSS Statistics for Windows, Version 19.0., Released 2010, IBM Corp., Armonk, NY, USA).

실험에 사용된 재료의 증거표본은 경희대학교 이과대 학 생물학과 식물표본실(KHUS)에 보관하였으며, 해부학 적 형질에 관한 용어의 기재는 Wilkinson (1979), Araújo et al. (2010)을 따랐다.

\section{결 과}

최근 Potter et al. (2007)의 장미과 분류체계에 따른 쉬땅나 무족 4속과 Schulze-Menz (1964)의 이전 분류체계에서 본 족 에 포함되어 인식되었던 Lyonothammus 속을 포함한 15 분류군 (Adenostoma속 2종, Chamaebatiaria속 1종, Lyonothammus속 2 종, Sorbaria속 9종, Spiraeanthus속 1종) 잎의 해부학적 형질을 관찰하고 기재하였다. 16 개의 잎의 해부학적 형질들(중륵의 외형, 날개 유무, 피층의 구조, 결정체, 모용, 중륵 크기, 유관

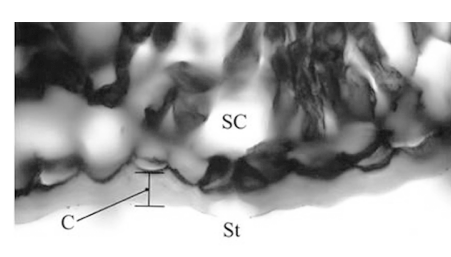

(A)
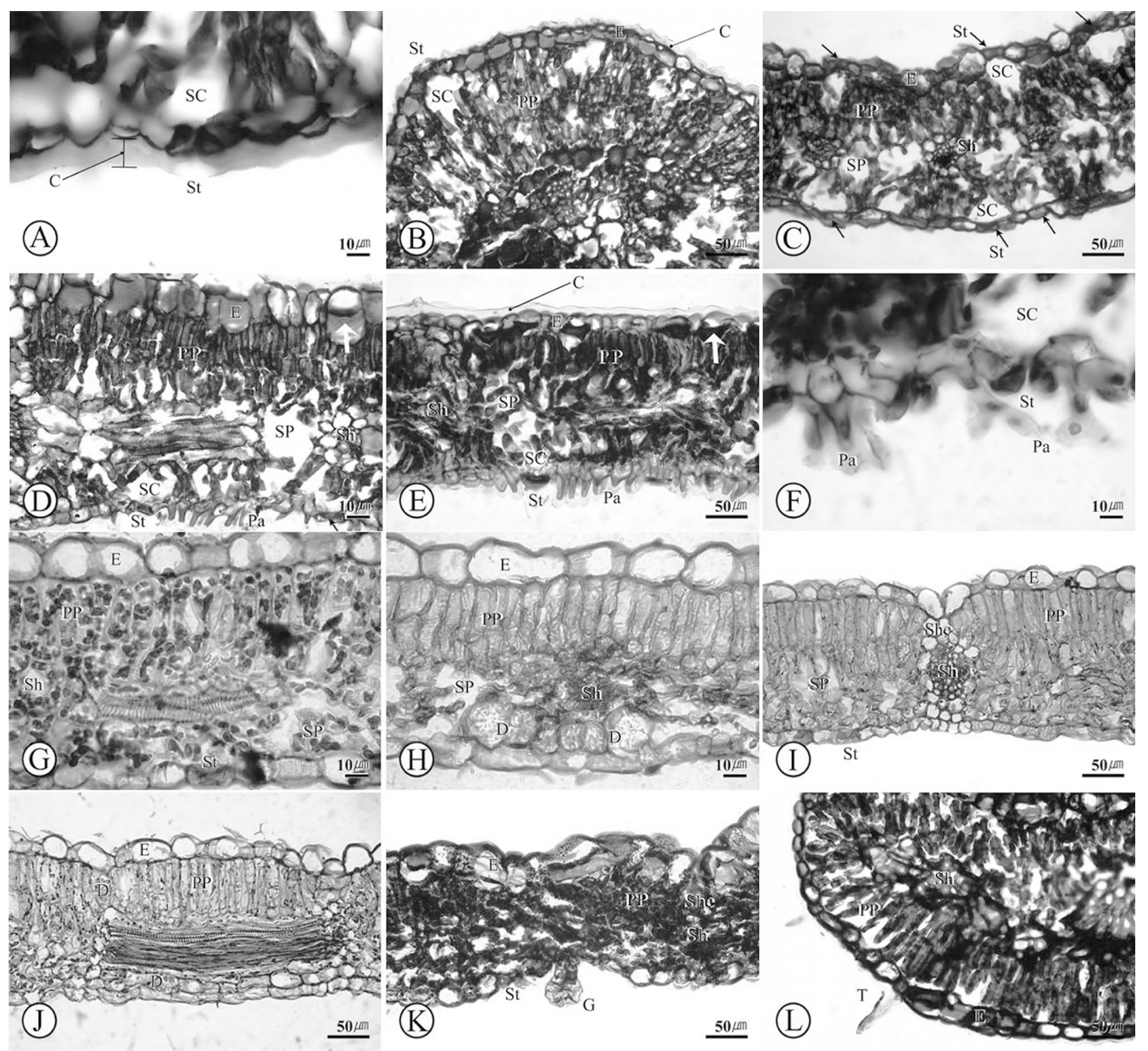

Fig. 1. Leaf blade cross-sections of the tribe Sorbarieae. A, Adenostoma fasciculatum; B, Adenostoma sparsifolium; C, Chamaebatiaria millefolium; D, Lyonothamnus floribundus; E-F, Lyonothamnus floribundus subsp. aspleniifolius; G, Sorbaria arborea; H, Sorbaria grandiflora; I-J, Sorbaria kirilowii; K, Sorbaria pallasii; L, Spiraeanthus schrenkianus. C, cuticle; D, druse; E, epidermis; G, glandular trichome; Pa, papilla; PP, palisade parenchyma; SC, sub-stomatal cavity; Sh, bundle sheaths; She, bundle sheath extension; SP, spongy parenchyma; St, stomata; T, trichome; Black arrow-stomata; White arrow-bilayered epidermis. 
(A)
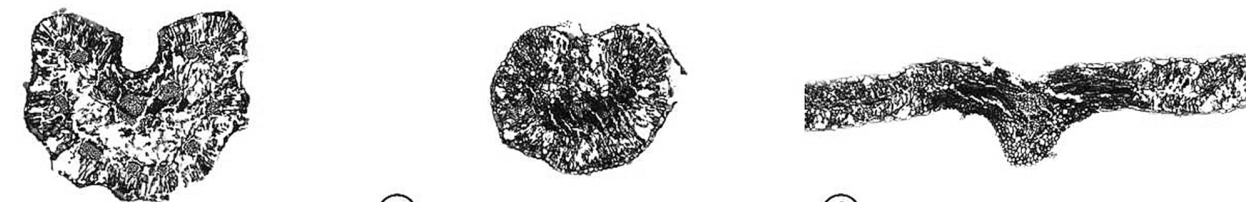

(B)

1000im (C)

100 /m
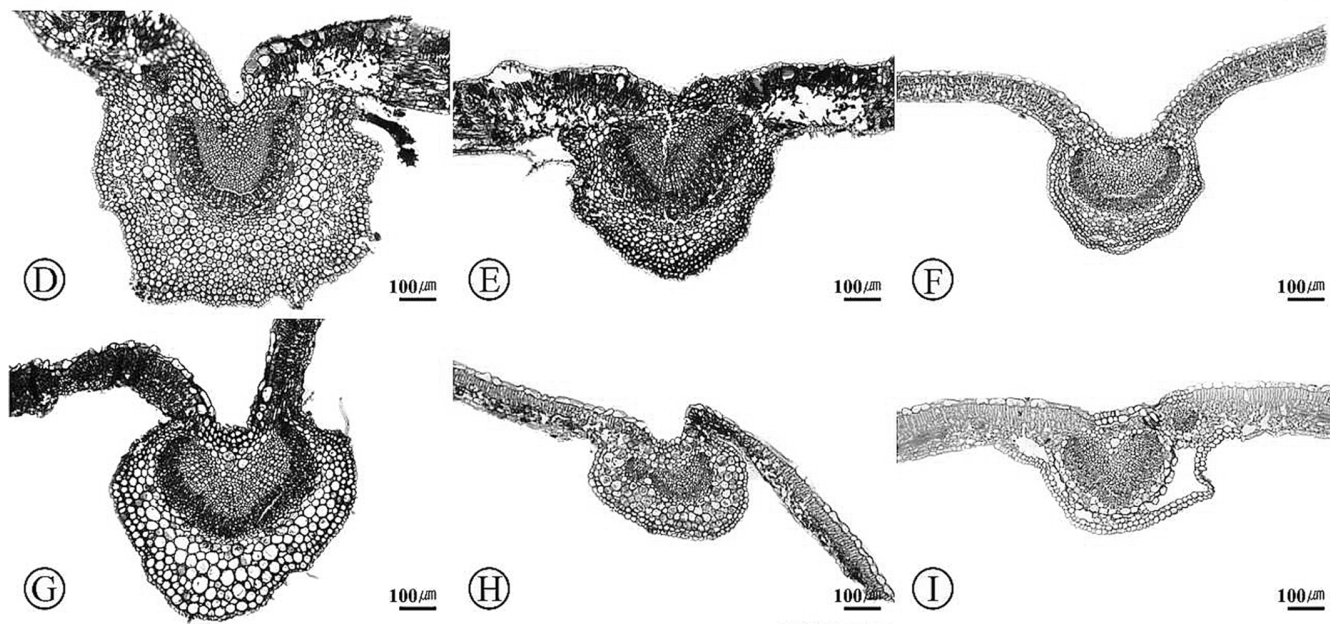

100/m (H)
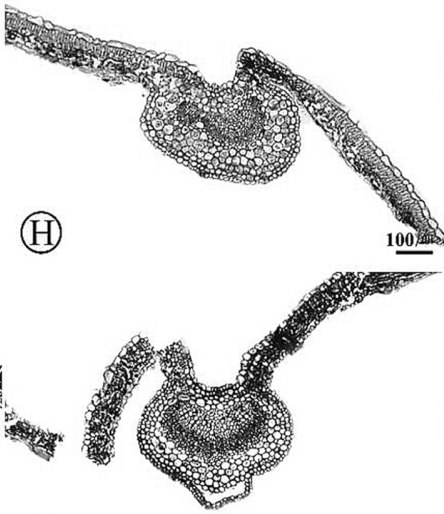

(J)
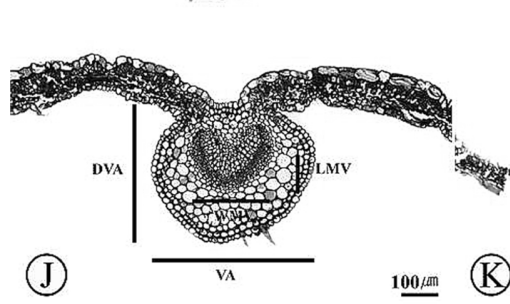

(K)

100 (I)

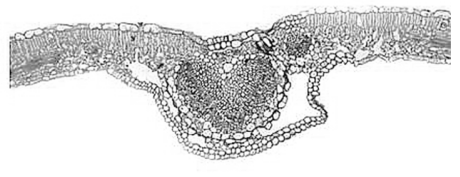

(I)

$100 / \mathrm{m}$

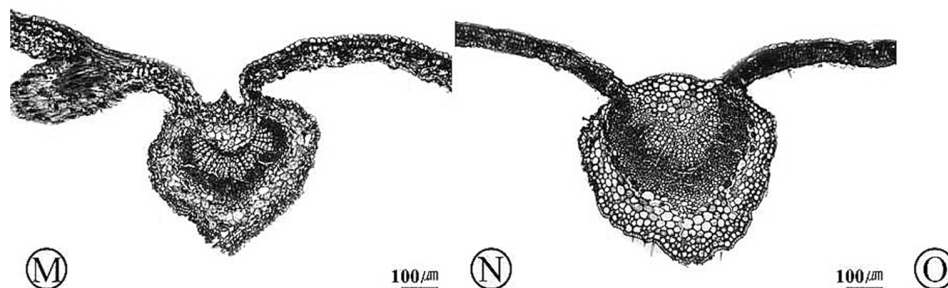

$100 / \mathrm{m}$
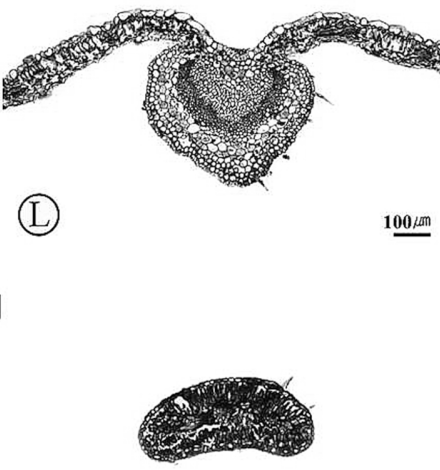

)

$\underline{100 \mu \mathrm{m}}$

(M)

100/m $\mathbb{N}$

100/m ()

100/m

Fig. 2. Cross-sections of the leaf midrib in the tribe Sorbarieae. A, Adenostoma fasciculatum; B, Adenostoma sparsifolium; C, Chamaebatiaria millefolium; D, Lyonothamnus floribundus; E, Lyonothamnus floribundus subsp. aspleniifolius; F, Sorbaria arborea; G, Sorbaria arborea var. subtomentosa; H, Sorbaria grandiflora; I, Sorbaria kirilowii; J, Sorbaria pallasii; K, Sorbaria sorbifolia; L, Sorbaria sorbifolia var. stellipila; M, Sorbaria sorbifolia f. incerta; N, Sorbaria tomentosa; O, Spiraeanthus schrenkianus.

속 구조 및 크기, 엽신의 구조 등)은 Table 1에 제시하였다.

중륵(midrib)의 구분이 어렵고, 날개(wing)를 형성하지 않는 Adenostoma속과 Spiraeanthus속은 각각 잎과, 소엽의 중앙부분을 절단하여 엽신으로 관찰하여 기재하였고, 날 개를 형성하는 Chamaebatiaria속, Lyonothammus속, Sorbaria 속은 소엽의 엽신(leaf blade; 날개부분: wing)과 중륵을 구 분하여 관찰, 기재하였다.

\section{1. 엽신(Leaf blade)}

1) 횡단면 잎의 외형(shape of leaf in cross section)

Adenostoma속, Spiraeanthus속에서 날개를 형성하지 않
는 원형, 아원형이었으며(Fig. $2 \mathrm{~A}, \mathrm{~B}, \mathrm{O})$, 나머지 분류군에 서는 날개를 형성하였다(Fig. 2C-N).

2) 횡단면 엽신의 두께(thickness of leaf blade in cross section)

연구된 분류군의 엽신의 두께는 중륵을 형성하고 주맥 부분을 제외한 날개부분(wing)이 나타나는 분류군을 기

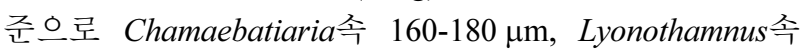
220-270 $\mu \mathrm{m}$, Sorbaria속 50-180 $\mu \mathrm{m}$ 으로 나타났다. 날개를 형성하는 소엽의 경우, Sorbaria tomentosa 가 50-70 $\mu \mathrm{m}$ 로 가장 얇게 관찰되었다(Table 1). 


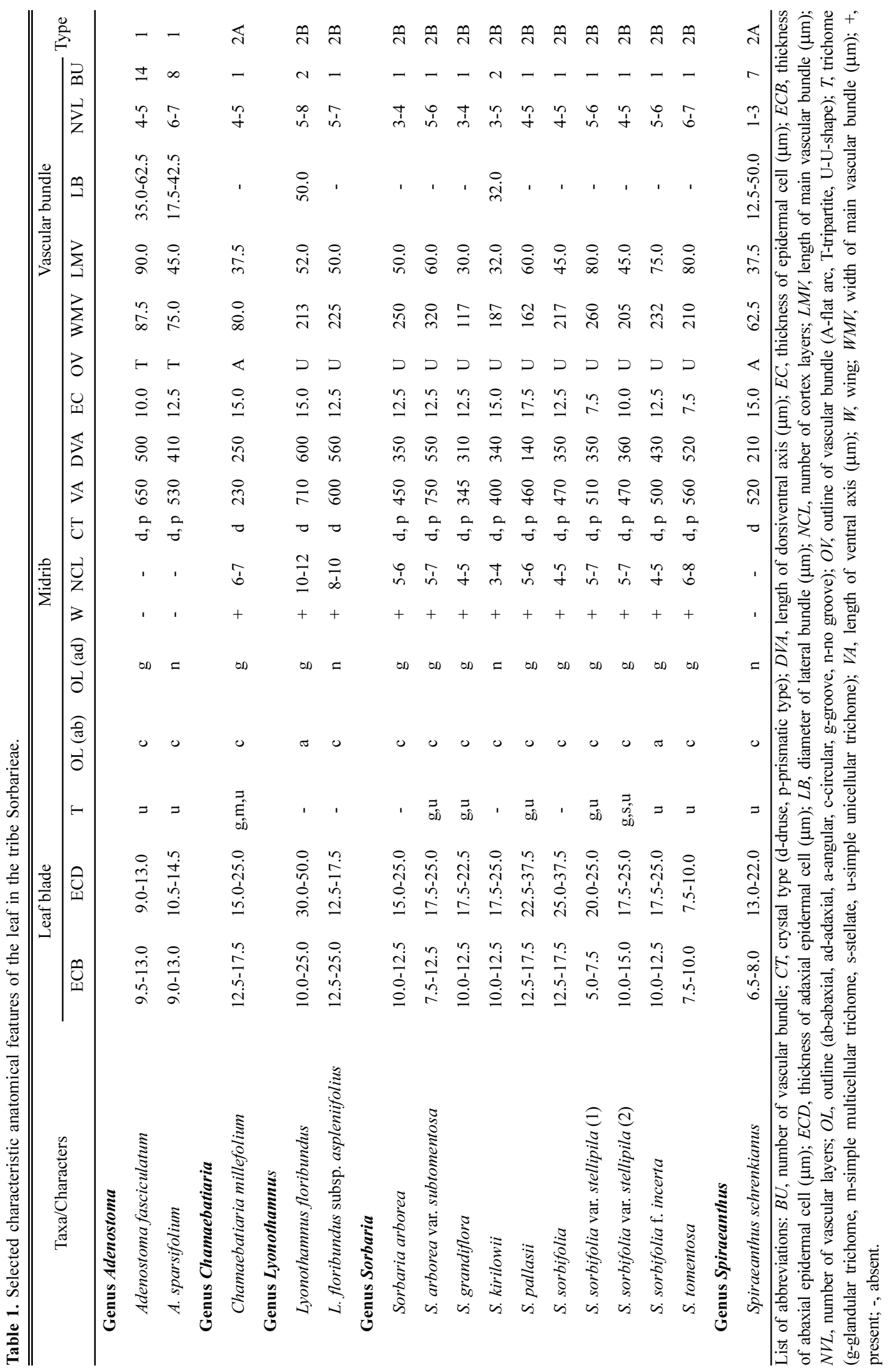




\section{3) 각피충(cuticle)}

Adenostoma속(Fig. 1A, B), Lyonothamnus 속(Fig. 1E), Spiraeanthus 속(Fig. 1L)에서만 각피층이 잘 발달하였고, 나머지 분류군에서는 미비하게 나타났다. 각 분류군별로 배축면에서 $0.7-4.3 \mu \mathrm{m}, 2.8-8.5 \mu \mathrm{m}, 1.5-2.5 \mu \mathrm{m}$ 로 나타났고, 향축면에서 각각 $3.0-9.5 \mu \mathrm{m}, 5.4-10.0 \mu \mathrm{m}, 2.0-3.5 \mu \mathrm{m}$ 로 나 타나 잘 발달된 각피층이 나타나는 분류군에서 모두 향축 면이 더 두꺼운 것으로 나타났다.

4) 표피세포(epidermal cell)

표피세포는 Lyonothammus속을 제외한 모든 분류군의 배
축면, 향축면에서 단일층(single-layered)으로 나타났으며, Lyonothamnus 속 두 분류군(L. floribundus, L. floribundus subsp. aspleniifolius)의 향축면에서만 불연속적인 이중층(noncontinuous bilayered)이 나타났다(Fig. 1D, E). 표피세포의 크기 는 배축면과 향축면에서 차이가 나타났는데, 배축면의 표 피세포(ECB)와 향축면의 표피세포(ECD)의 두께는 각각 Adenostoma속: 9.0-13.0 $\mu \mathrm{m}, 9.0-14.5 \mu \mathrm{m}$; Chamaebatiaria속: 12.5-17.5 $\mu \mathrm{m}, 15.0-25.0 \mu \mathrm{m}$; Lyonothamnus 속: 10.0-25.0 $\mu \mathrm{m}$, 12.5-50.0 $\mu \mathrm{m}$; Sorbaria속: 5.0-17.5 $\mu \mathrm{m}, 7.5-37.5 \mu \mathrm{m}$, Spiraeanthus 속: $6.0-8.0 \mu \mathrm{m}, 13.0-22.0 \mu \mathrm{m}$ 로 Adenostoma속을 제외한 나머지 모든 분류군에서 향축면의 표피세포 크기가 배축

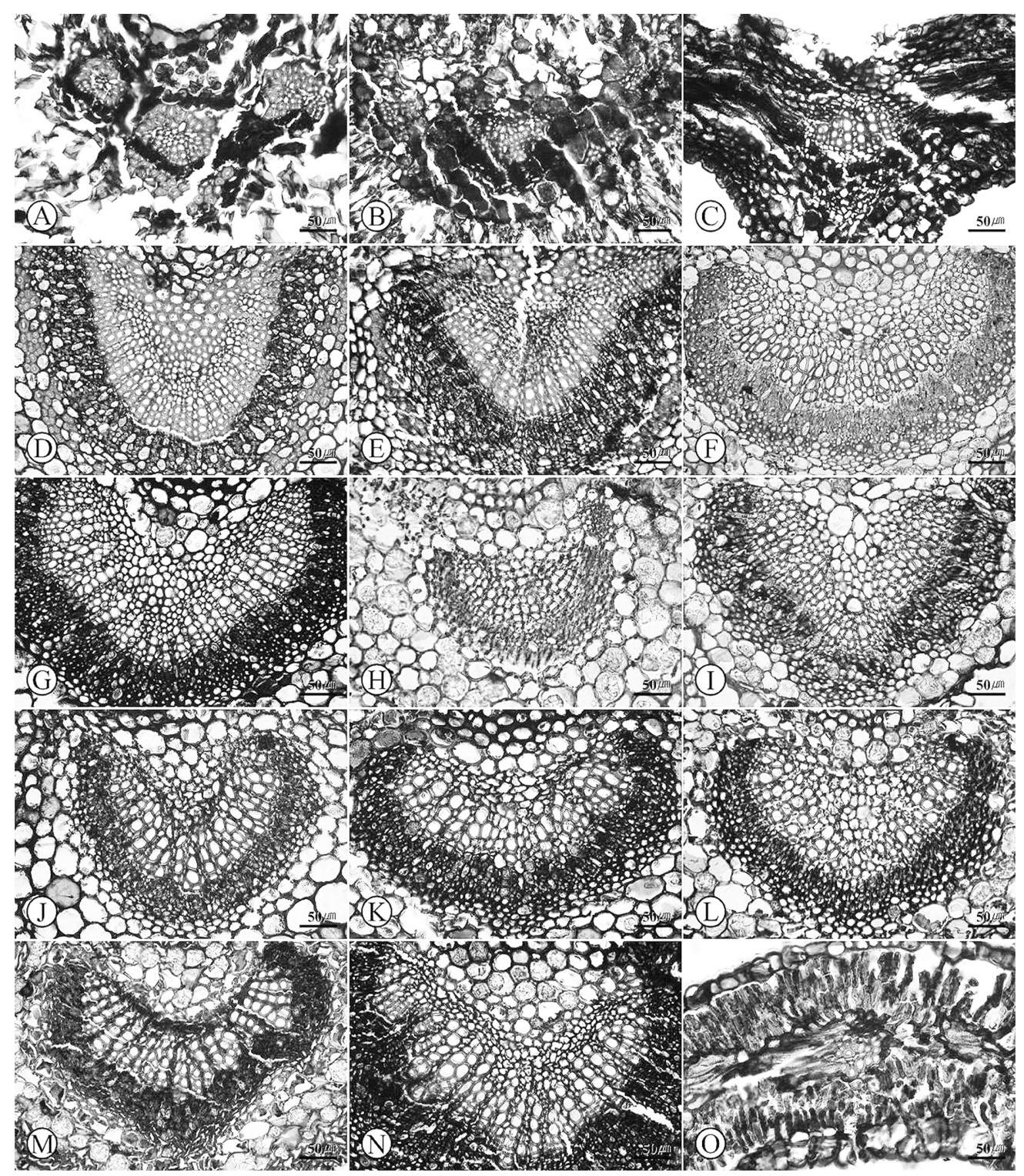

Fig. 3. Vascular bundle structure of the leaf blade (midrib) in the tribe Sorbarieae. A, Adenostoma fasciculatum; B, Adenostoma sparsifolium; C, Chamaebatiaria millefolium; D, Lyonothamnus floribundus; E, Lyonothamnus floribundus subsp. aspleniifolius; F, Sorbaria arborea; G, Sorbaria arborea var. subtomentosa; H, Sorbaria grandiflora; I, Sorbaria kirilowii; J, Sorbaria pallasii; K, Sorbaria sorbifolia; L, Sorbaria sorbifolia var. stellipila; M, Sorbaria sorbifolia f. incerta; N, Sorbaria tomentosa; O, Spiraeanthus schrenkianus. 
면에 비해 약 1.5-2.5배정도 크게 나타났다(Table 1). 표피세 포의 모양은 타원형(elliptic), 장타원형(oblong)에서 원형 (circular), 사각형(square)으로 관찰되었다(Fig. 1). 특히 Lyonothammis속에서만 배축면에 원뿔형(cone)과 가지형(branched)의 유두상(papillae) 세포가 확인되었다(Fig. 1D-F).

\section{5) 기공(stomata)}

기공은 Adenostoma속, Chamaebatiaria속, Lyonothammus속, Spiraeanthus 속에서 양면기공엽(amphistomatic type)이 나타 났고, Sorbaria속에서만 이면기공엽(hypostomatic type)이 나 타났다. 특히 Adenostoma속 두 분류군과 Spiraeanthus속에 서만 공변세포 내 잘 발달된 cuticular ledges가 관찰되었고,
모든 분류군에서 기공 밑 세포 간극(sub-stomatal chamber) 이 확인되었다(Fig. 1A).

\section{6) 모용(trichome)}

모용은 크게 비선모(non-glandular trichome)와 선모 (glandular trichome) 두 가지가 확인되었다. 비선모 모용에는 단세포 단모(simple unicellular non-glandular trichome), 다세포 단모(simple multicellular non-glandular trichome), 성상모 (stellate)로 구분되었다. 단세포 단모는 Lyonothammus속과 Sorbaria속 일부 분류군을 제외한 모든 분류군에서 관찰되 었으며(Fig. 4F, K, N, S, T), 다세포 단모는 Chamaebatiaria속 에서만 확인 되었고(Fig. 4E), 성상모는 쉬땅나무(S. sorbifolia

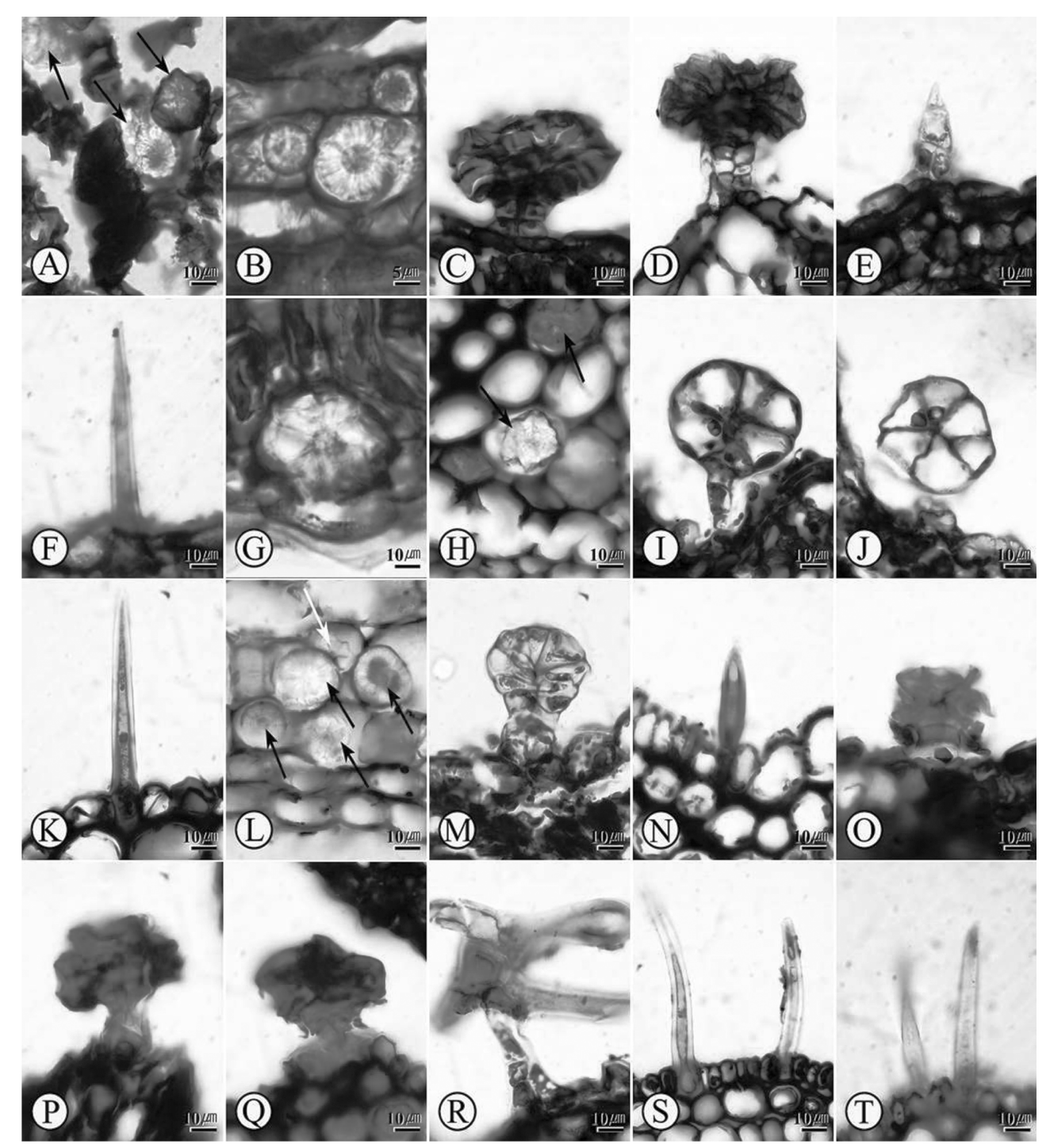

Fig. 4. Crystal types and trichomes of leaf blade in the studied taxa. A, Adenostoma fasciculatum; B-F, Chamaebatiaria millefolium; G, Lyonothamnus floribundus subsp. aspleniifolius; H-K, Sorbaria arborea var. subtomentosa; L, Sorbaria grandiflora; M-N, Sorbaria pallasii; O-Q, Sorbaria sorbifolia var. stellipila (1); R-S, Sorbaria sorbifolia var. stellipila (2); T, Sorbaria tomentosa; glandular trichome (C, D, I, J, M, O, P, Q); simple multicellular non-glandular trichome (E); simple unicellular non-glandular trichome (F, K, N, S, T); stellate (R); Black arrow-druse type crystal; White arrow-prismatic type crystal. 
var. stellipila)에서만 확인되었다(Fig. 4R). 선모(glandular trichome)는 Chamaebatiaria속(Fig. 4D), Sorbaria arborea var. subtomentosa (Fig. 4I, J), S. grandiflora, S. pallasii (Fig. 4M), S. sorbifolia var. stellipila에서 긴 자루 $(>30 \mu \mathrm{m})$ 의 두상선모가 관 찰되었고, Chamaebatiaria속(Fig. 4C), S. sorbifolia var. stellipila (Fig. $4 \mathrm{O}, \mathrm{Q})$ 에서는 짧은 자루 $(<30 \mu \mathrm{m})$ 의 두상선모와 함께 관찰되었다. 특히 쉬땅나무 일부 분류군에서 많은 수의 짧 은 자루, 긴 자루의 두상선모가 관찰되었다(Fig. 4O-Q).

\section{7) 엽육조직(mesophyll)}

엽육조직은 Lyonothammus속(Fig. 1D-E)과 Sorbaria속 (Fig. 1G-K)에서만 배복성(dorsiventral)이 나타났고, 나머 지 분류군에서는 모두 쌍동측성(isobilateral)으로 관찰되 었다(Fig. 1B-C, L). 쌍동측성 분류군에서 책상조직 (palisade parenchyma)은 배축면 2-3층, 향축면 1-3층으로 확인되었고, 배복성인 Lyonothamnus속, Sorbaria속은 모두 향축면에 1 개의 책상조직층으로 나타났다(Fig. 1D-E, G$\mathrm{K})$. 해면조직(spongy parenchyma)은 대부분 전체 잎 두께 의 약 $1 / 2$ 정도를 차지하고 있다. 유관속(vascular bundle)은 병립유관속(collateral)으로 배축면에 사부(phloem), 향축 면에 목부(xylem)가 존재하며, 대부분의 분류군에서 유관 속은 유관속초(bundle sheath)에 둘러싸여 있다(Fig. 1C, E, G-I, K-L). 또한 대부분의 분류군에서 유관속초 확장부위 (bundle sheath extension)를 형성하였다(Fig. 1I, K).

\section{8) 결정체(crystal)}

연구된 모든 분류군의 엽신에서 선정체(druse)가 나타 났다(Table 1; Fig. 4A, 4B, 4G).

\section{2. 중륵(Midrib)}

1) 횡단면 중륵의 크기(size of midrib in cross section)

배축면의 길이(VA)와 등축면으로부터 배축면으로 향 한 길이(DVA)에서 각각 Adenostoma속: $530-650 \mu \mathrm{m}, 410-$
$500 \mu \mathrm{m}$; Spiraeanthus속: $230 \mu \mathrm{m}, 250 \mu \mathrm{m}$ 이었고, 중륵이 나 타나는 분류군의 중륵의 크기는 각각 Chamaebatiaria속: $230 \mu \mathrm{m}, 250 \mu \mathrm{m}$; Lyonothamnus 속: 600-710 $\mu \mathrm{m}, 560-600 \mu \mathrm{m}$; Sorbaria속: $345-750 \mu \mathrm{m}, 140-550 \mu \mathrm{m}$ 으로 나타났다(Table 1). 잎의 등축면으로부터 배축면으로 향한 길이는 배축면 의 길이와 유의한 상관관계를 보였다(DVA와 $\mathrm{VA}: \mathrm{r}=0.75$, $p<0.05$; Fig. 5A).

\section{2) 피충(cortex)}

조사된 모든 분류군의 중륵에서 대부분 규칙형(isometric) 이 나타났으며, 피층의 층수(NCL)는 Chamaebatiaria속 6-7 개, Lyonothammus 속 8-10개, Sorbaria속 3-8개로 관찰되었다 (Table 1).

\section{3) 결정체(crystal)}

Chamaebatiaria속, Lyonothamnus속, Spiraeanthus속에서 는 선정체만이 관찰되었고, Adenostoma속, Sorbaria속에서 는 선정체와 프리즘형(prismatic type)이 동시에 나타났다 (Table 1; Fig. 4H, 4L).

\section{4) 주유관속 유형(main vasculature type)}

잎 중륵의 유관속은 병립유관속으로 모두 호형 $(\operatorname{arc})$ 인 개방형(open)이었는데, 유관속의 연속성으로 크게 두 타 입으로 구별하였다. Type 1인 Adenostoma속은 불연속 유 관속으로 호형인 독립된 3 개의 유관속 배열이 나타나 다 른 분류군과 구별되었다(Fig. $3 \mathrm{~A}, \mathrm{~B})$. Type 2 는 연속 유관속 으로 유관속의 형태에 따라 두 개의 subtype으로 구분하였 다. Type 2A인 Chamaebatiaria속, Spiraeanthus 속은 다소 편 평(flat)한 호형을 나타냈고(Fig. $3 \mathrm{C}, \mathrm{O})$, Type $2 \mathrm{~B}$ 인 Lyonothamnus 속, Sorbaria속은 U-shape의 호형이 나타나 구별되었다(Fig. $3 \mathrm{D}-\mathrm{N}$; Table 1). 연구된 분류군 중 Adenostoma속과 Lyonothammus 속에서만 유관속 주변으로 섬유조직(fiber)이 확인되었다(Fig. 3A-B, 3D-E).

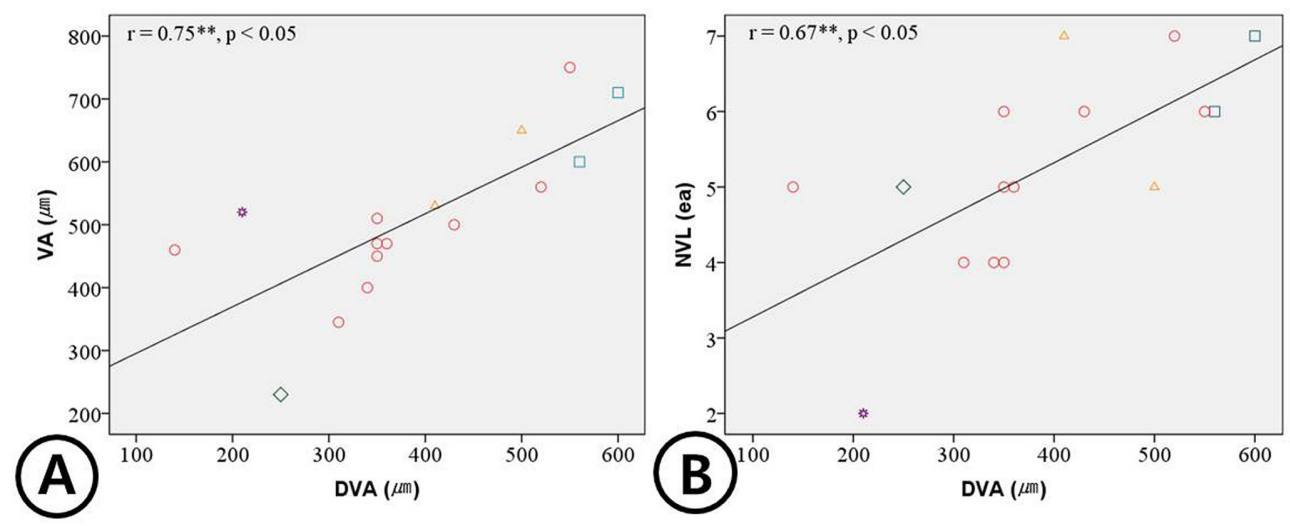

Fig. 5. Simple scatter plots between leaf blade anatomical variables (black line showed regression line). Change in (A) VA and (B) NVL according to increasing of DVA. - List of abbreviations: DVA, length of dorsiventral axis; NVL, number of vascular layers; VA, length of ventral axis; Triangle $(\triangle)$, Adenostoma; Diamond $(\diamond)$, Chamaebatiaria; Square $(\square)$, Lyonothamnus; Circle $(\bigcirc)$, Sorbaria; Astral $(*)$, Spiraeanthus. 


\section{5) 유관속 크기(size of vascular bundles)}

중심축의 유관속 너비(WMV)는 Adenostoma속: 75.0$87.5 \mu \mathrm{m}$, Chamaebatiaria속: $80.0 \mu \mathrm{m}$, Lyonothamnus 속: 213$225 \mu \mathrm{m}$, Sorbaria속: 162-320 $\mu \mathrm{m}$ 로 나타났고, 중심축의 유 관속 길이(LMV)는 Adenostoma속: 45.0-90.0 $\mu \mathrm{m}$, Chamaebatiaria속: $37.5 \mu \mathrm{m}$, Lyonothamnus 속: 50.0-52.0 $\mu \mathrm{m}$, Sorbaria속: 30.0-80.0 $\mu \mathrm{m}$ 로 나타났다(Table 1).

\section{6) 측유관속(lateral vascular bundles)}

측유관속(LB)은 Adenostoma속, Lyonothamnus floribundus, Sorbaria kirilowii, Spiraeanthus속에서만 나타나 구별되었다 (Table 1).

\section{7) 유관속 층수(number of vascular layers)}

Adenostoma속 4-7개, Chamaebatiaria속 4-5개, Lyonothamnus속 5-8개, Sorbaria속 3-7개, Spiraeanthus 속 13 개로 관찰되었고, 잎의 등축면으로부터 배축면으로 향 한 길이가 유관속 층수와 유의한 상관관계를 나타냈다 (DVA와 NVL: $\mathrm{r}=0.67, p<0.05$; Fig. $5 \mathrm{~B}$ ).

\section{8) 유관속 수(number of vascular bundles)}

Adenostoma속 8-14개, Chamaebatiaria속 4-5개, Lyonothamnus 속 1-2개, Sorbaria속 1-2개, Spiraeanthus 속 7개로 관 찰되었다.

\section{고 찰}

쉬땅나무족에 속하는 4속의 잎과 소엽의 외형은 그 모 양과 배열에 있어 상당한 차이가 나타난다. Adenostoma속 의 경우 단엽은 단단한 선형으로 침엽과 유사한 형태 (needle-like form)를 나타내고(Jepson, 1993), Chamaebatiaria속은 2-3회 우상복엽으로 양치식물의 포자엽과 유사 한 형태(fern-like form)를 나타낸다(Cullen, 2001). Sorbaria 속은 일반적인 우상복엽의 형태를 보이며(Lee, 2007), Spiraeanthus 속은 좁은 선형의 우상복엽으로 20-35개의 소 엽으로 구성되는데, Chamaebatiaria속과 유사하게 전체적 으로 양치엽과 비슷한 형태를 보인다(Komarov, 1939). Lyonothamnus 속은 전연의 단엽 형태인 L. floribundus subsp. floribundus와 깊게 우상으로 갈라져 보이는 형태 (pinnatifid)인 L. floribundus subsp. aspleniifolius으로 구분된 다(Raven, 1963; Jepson, 1993; Kalkman, 2004).

횡단면 잎의 외형에서 Adenostoma속, Spiraeanthus속에 서 날개를 형성하지 않아 구분할 수 있었으며, 나머지 분 류군은 중륵과 엽신이 관찰되어 구분되었다.

각피층은 Adenostoma속, Lyonothamnus속, Spiraeanthus 속에서 잘 발달되어, 미비하게 나타난 Chamaebatiaria속, Sorbaria속과 구분할 수 있었다. 각피층의 두께는 다양한 환경조건과 반응하는 것으로 알려져 있는데, 빛이 강하거
나 건조할수록 또는 고도가 높아질수록 두께가 두꺼워 진 다고 보고된 바 있다(Eberhardt, 1903; Schroeter, 1923; Skoss, 1955; Wilkinson, 1979). 각피층이 잘 발달된 Adenostoma속은 미국의 캘리포니아주(특히, A. fasciculatum는 Sierra Nevada), 멕시코의 바하칼리포르니아에 자 생하는 식물로 알려져 있고(Jepson, 1993), Lyonothamnus속 역시 캘리포니아 채널 제도의 고유종으로 협곡 바위지대 에 서식하는 것으로 알려져 있으며(Raven, 1963; Jepson, 1993; Kalkman, 2004), Spiraeanthus속은 카자흐스탄 고유 종으로 Karatau 산악지역과 Betpak-Dala 사막에 서식하는 것으로 보고되어 있다(Kamelin, 1990). 세 속의 해당 서식 지역은 모두 햇빛이 강하거나 건조한 기후대에 속해 각피 층의 두께는 생태적 환경과 연관이 깊다는 기존의 의견을 지지하였다.

Araújo et al. (2010)은 표피세포에서 나타나는 단일층과 이중층의 형질이 Malpighiaceae에 속하는 일부 분류군을 인식하는데 유용하다고 밝힌 바 있다. 또한, Wilkinson (1979)은 표피세포에서 나타나는 유두상 세포에 대해 형 태학적으로 구별되는 유두상 세포의 타입을 진단형질로 이용할 수 있다고 기술하였다. 본 연구 분류군 중 Lyonothamnus 속 표피세포에서만 향축면에서 불연속적인 이중층이 나타나고, 배축면에서 원뿔형과 가지형의 유두 상 세포가 나타나 나머지 쉬땅나무족 분류군과 구별되는 형질로 확인되었다.

기공은 Sorbaria속에서만 이면기공엽이 나타나고 나머 지 분류군에서 양면기공엽이 나타나 구별되었다. Parkhurst (1978)는 일반적으로 중생식물(mesophytic species)의 경우 이면기공엽이 더 빈번히 나타나고, 매우 건조하거나 혹은 매우 습한 환경에 서식하는 분류군에서 는 양면기공엽의 빈도가 높게 나타난다고 주장한 바 있다. 본 연구 분류군에서는 양면기공엽이 나타나는 Adenostoma 속과 Chamaebatiaria속, Spiraeanthus속의 서식환경이 모두 고온 건조한 사막지역이고, Lyonothamnus속은 채널제도 바위 지대로 Parkhurst (1978)의 주장과 일치하였다. 공변 세포 유형에 대해서는 cuticular ledge의 형태가 인식형질 로서 중요하다고 보고된 바 있는데(Solereder, 1908), 본 연 구에서는 Adenostoma속과 Spiraeanthus 속에서만 잘 발달 된 cuticular ledge가 확인되어, 다른 분류군과 구별하는 인 식형질로 유용함을 밝혔다.

본 연구에서 3종류의 비선모와 2종류의 선모가 확인되 었는데, 다세포 모용은 Chamaebatiaria속에서만 확인 되 었고, 성상모는 쉬땅나무(S. sorbifolia var. stellipila)에서만 확인되어, 다세포 비선모와 성상모가 연구된 분류군의 인 식형질로 이용되는데 유용하였다. 선모 역시 Chamaebatiaria속과 Sorbaria속 일부 분류군에서 관찰되어 구분할 수 있었다. Rahn (1989)은 Sorbaria속 내 크게 4가지 타입의 모용을 기재하였는데, 본 연구 결과와는 일부만이 일치하 였다. 이는 전체 잎의 구조 중 일부 단편만을 관찰하게 되 
는 해부학적 결과의 한계로 여겨지며, 많은 수의 표본 조 사를 통해 개체 및 지역적 분포에 따른 모용의 종류와 빈 도를 정확히 파악할 필요성이 있다(Song in prep.). 선모의 빈도에 있어 쉬땅나무 분류군 중 강원도 점봉산에서 채집 된 표본(T. B. Lee s.n., SNUA)에서 높게 나타나 구별되었는 데, Nakai가 잎 뒷면에 선점이 분포한다는 특징으로 鮮滿 實用林業便覽(鏑木德二, 1940)에 발표한 점쉬땅나무 (Sorbaria stellipila Schneid. var. glandulosa Nakai)의 형질과 일치하였다. 하지만, 본 학명은 비합법명으로 재고된 상 태이기 때문에(Chang and Kim, 2002; Kim et al., 2005), 다양 한 형질조사를 통한 점쉬땅나무의 실체 파악과 분류학적 처리가 필요하다(Song in prep.).

기공엽의 종류와 엽육조직의 형태는 서식지 환경요인[ 햇볕의 세기(일사량) - 광합성유효방사(PAR; photosynthetic active radiation); 건습 - 수분스트레스(water stress)]과 높은 연관성이 나타난다(Smith et al., 1997, 1998). 일사량 이 높은 서식지 내에서, 수분 스트레스가 낮은 지역에서 는 양면 혹은 이면기공엽과 배복성의 엽육조직을 지닌 분 류군들이 빈번하게 확인되고, 수분 스트레스가 높은 지역 에서는 양면기공엽과 쌍동측성의 분류군들이 확인된다. 또한 일사량이 낮은 서식지 내에서는 수분 스트레스의 정 도에 따라 양면기공엽과 배복성 혹은 책상조직층이 없는 분류군들이 나타난다(Smith et al., 1997, 1998). 본 연구 분 류군 중 양면기공엽과 쌍동측성 엽육조직이 관찰된 Adenostoma속, Chamaebatiaria속, Spiraeanthus 속은 일사량과 수 분 스트레스가 높은 고온 건조한 사막지대에 서식하고, 양 면기공엽과 배복성이 나타난 Lyonothamnus속은 일사량은 높지만 비교적 수분 스트레스가 낮은 섬 지대에 서식하며, 이면기공엽과 배복성이 확인된 Sorbaria속은 일사량과 수 분스트레스가 비교적 낮은 온대지역에 서식한다. 따라서, 서식 환경요인과 기공엽, 엽육조직 형질 간의 높은 연관성 을 제시한 Smith et al. (1997, 1998)의 의견을 지지하였다.

결정체는 식물체의 물리적인 보호와 oxalate의 방출, 칼 슘의 저장, 광합성 중 빛의 조절 등 다양한 기능과 연관이 있는 것으로 알려져 있다(Franceschi and Nakata, 2005). Metcalfe and Chalk (1985)는 결정체의 종류와 분포패턴이 분류학적으로 유용한 형질로 작용한다고 주장하였다. 본 연구에서는 모든 분류군의 엽신에서 선정체가 관찰되었 고, 특히 중륵 부위에서는 Adenostoma속과 Sorbaria속에서 선정체와 프리즘형이 동시에 관찰되어 구별되었다. Sorbaria속에서는 주유관속 주변에 많은 수의 선정체가 확인되었는데, 이는 Adenostoma속과 Lyonothamnus속에서 나타나는 섬유와 마찬가지로 유관속을 물리적으로 지지 하는 기능을 하는 것으로 판단되었다.

Viguier (1906)와 Metcalfe and Chalk (1950)은 잎의 해부 학적 형질 중 유관속의 패턴과 개수가 분류학적으로 상당 히 유용하다고 주장한 바 있다. 본 연구에서도 Lyonotham$n u s$ 속, Sorbaria속과 나머지 분류군을 주유관속의 유형과
유관속 수로 구분할 수 있어, 본 형질의 유용성을 확인 할 수 있었다. 또한 중륵과 유관속의 관계에 있어, 잎의 등축 면에서 배축면으로 향한 길이(DVA)가 증가할수록 유관 속층수 $(\mathrm{NVL})$ 가 증가하는, 일정한 양의 상관관계를 확인 하였다 $(\mathrm{r}=0.67, p<0.05)$. 이는 중륵, 잎의 두께가 두꺼울 수록 유관속의 층을 늘려 많은 양의 수분을 수송하는 것 으로 판단되었다.

최근 Potter et al. (2007)의 장미과 분자계통학적 연구에 따르면, Lyonothamnus 속은 조팝나무아과에 포함되나 족 내 분류학적 위치를 찾지 못하고 있다. 잎의 해부학적 형 질에 의해서는 일부 Sorbaria속과 공유하는 형질이 있으 나, 배축면의 유두상 표피세포와 향축면에 나타나는 이중 층의 특징으로 Lyonothamnus 속은 나머지 쉬땅나무족 분 류군과 구분된다. Song and Hong (unpubl. data)의 쉬땅나무 족 ITS 염기서열에 근거한 분자계통분석에서도 Lyonotha$m m u s$ 속이 연구 분류군 내 가장 기부에 분지되어 표피세포 의 형질이 Lyonothamnus 속과 쉬땅나무족을 구분하는 매 우 유용한 형질임이 확인되었다.

쉬땅나무족 내에서는 Adenostoma속에서만 중륵의 유관 속 패턴이 불연속 호형으로 나타나 연속 호형인 다른 분 류군과 구분되었다. 이는 수과의 열매를 갖는 특징 및 침 엽과 유사한 잎의 외부형태학적 차이와 더불어 족 내 다 른 분류군과의 뚜렷한 차이를 나타낸다. 또한, 쉬땅나무 속에서는 단면기공엽과 배복성의 엽육조직, U-shape의 유 관속 패턴 등의 독립된 형질이 나타나 다른 속과 구분되 어, 이들 형질이 족 내 쉬땅나무속을 구분하는 주요형질 임을 확인하였다. 분자계통학적 연구를 기반으로 한 종합 적인 형질 고찰을 통해 족 내에서 속 간 뚜렷하게 구분되 는 형질 및 형질진화에 대한 연구가 수행되어야 할 것이 다. 더불어, 장미과 내 확장된 분류군의 해부학적 연구를 통해 유용한 형질로 판단된 이들 형질의 전반적인 진화적 경향성을 파악해야 할 것이다.

결론적으로, 본 연구는 쉬땅나무족에 포함된 4개 속과 연 관 분류군인 Lyonothammus 속 잎의 해부학적 형질을 관찰하 여 상세히 기재함으로써 장미과의 해부학적 기초자료를 확보하였고, 잎의 해부학적 형질과 환경과의 연관성에 대 해 고찰하였다. 또한 다양한 해부학적 형질 중, 잎의 각피 층, 표피 유두상 세포의 유무, 기공의 유형, 결정체 및 모용 의 종류와 유무, 유관속 패턴 및 수, 엽신의 조직구조 등의 형질이 진단형질로서 유용함을 확인하였다. 특히 표피세 포 형질의 중요성을 확인하였고, 해부학적 형질의 분류학 적 적용을 통해 기공, 엽육조직의 종류, 중륵의 주유관속 패 턴의 형질이 족 내 Sorbaria속의 주요 인식형질임을 밝혔다.

\section{사 사}

본 연구를 위해 귀중한 표본을 대여해주신 $\mathrm{A}, \mathrm{C}, \mathrm{GH}$, $\mathrm{KH}, \mathrm{KHUS}, \mathrm{MO}, \mathrm{PE}, \mathrm{SNUA}$ 의 각 표본관의 관계자께 감사 
를 드립니다. 또한 논문심사 과정 중 많은 조언과 보다 정 확한 논문이 되도록 교정을 해주신 익명의 두 분 심사자 들께 감사드립니다. 끝으로 본 연구과정에 여러모로 도움 을 아끼지 않은 경희대학교 생물학과 식물계통분류학 연 구실(KHUS)의 모든 동료들에게 고마운 마음을 전합니다. 본 연구는 한국연구재단 기본연구비(NRF-2012R1A1A 2004149)의 지원으로 수행되었으며, 이에 감사드립니다.

\section{인용문헌}

Agbaywa, I. O. and B. C. Noukwu. 2004. The value of morphoanatomical features in the systematic of Cucurbita species in Nigeria. African Journal of Biotechnology 3: 541-546.

Almeida, E. B. Jr., J. S. Araújo, F. S. Santos-Filho and C. S. Zickel. 2013. Leaf morphology an anatomy of Manilkara Adans. (Sapotaceae) from northeastern Brazil. Plant Systematics and Evolution 299: 1-9.

Araújo, J. S., A. A. Azevedo, L. C. Silva and R. M. S. A. Meira. 2010. Leaf anatomy as an additional taxonomy tool for 16 species of Malpighiaceae found in the Cerrado area (Brazil). Plant Systematics and Evolution 286: 117-131.

Chang, C. S. and H. Kim. 2002. Overlooked and invalidly published names of Korean woody plants. Korean Journal of Plant Taxonomy 32: 363-371. (in Korean)

Cullen, J. 2001. Handbook of North European Garden Plants. Cambridge University Press, Cambridge.

De Villiers, B. J., P. M. Tilney and E. B. Van Wyk. 2010. The taxonomic significance of leaf anatomical characters in Cussonia and related genera (Araliaceae). Botanical Journal of the Linnean Society 164: 246-263.

Eberhardt, P. 1903. Influence de l'air et de l'air humide sur la forme et sur la structure des végétaux. Annales des Sciences Naturelles Botanique Ser VIII. 18: 60-152.

Franceschi, V. R. and P. A. Nakata. 2005. Calcium oxalate in plants: Formation and function. Annual Review of Plant Biology 56: 41-71.

Gonçalves, M. M. B. and O. Rodriigo. 2003. Leaf anatomy of rubber tree clones. Scientia Agricola 60: 709-713.

Holmgren, P. K. and N. H. Holmgren. 1998. Index herbariorum. Retrieved Feb. 20, 2014, from http://sciweb.nybg.org/ science2/IndexHerbariorum.asp.

Hutchinson, J. 1964. The genera of flowering plants, Vol. 1. Dicotyledons. Clarendon Press, Oxford.

Jepson, W. L. 1993. Jepson manual: higher plants of California. University of California, Berkeley.

Kalkman, C. 2004. Rosaceae. In The Families and Genera of Vascular Plants, Vol. VI. Flowering Plants. Dicotyledons: Celastrales, Oxalidales, Rosales, Cornales, Ericales. Kubitzki, K. (ed.), Springer-Verlag, Berlin. Pp. 343-386.

Kamelin, R. V. 1990. Flora Syrdarinskogo Karatau: Materialy k floristicheskomu raionirovaniiu Srednei Azii. Nauka, Leningrad. (In Russian)

Kharazian, N. 2007. The taxonomy and variation of leaf anatomical characters in the genus Aegilops L. (Poaceae) in Iran. Turkish Journal of Botany 31: 1-9.

Komarov, V. L., 1939. Flora of the U.S.S.R., Vol. 4. Rosales and Sarraceniales. Izdatel"stvo Akademii Nauk SSSR. Moscow, Leningrad. Pub. by Israel Program for Scientific Translations Ltd., Jerusalem.

Kim, H., H. S. Lee, S. Park and C. S. Chang. 2005. Invalid names published by T. B. Lee. Korean Journal of Plant Taxonomy 35: 211-226. (in Korean)

Lee, J. H., O. W. Kwon, T. S. Jang, H. S. Roh and S.-P. Hong. 2010. The petiole anatomy of the genus Spiraea L. (Rosaceae) in Korea. Korean Journal of Plant Taxonomy 40: 16-26. (in Korean)

Lee, S. T. 2007. Sorbaria. In The Genera of Vascular Plants of Korea. Park, C.-W. (ed.), Academy Publishing Co., Seoul. Pp. 540-541.

Metcalfe, C. R. and L. Chalk. 1950. Anatomy of the dicotyledons, Vol II. $2^{\text {nd }}$ ed. Clarendon Press, Oxford.

Metcalfe, C. R. and L. Chalk. 1979. Anatomy of the dicotyledons: Systematic anatomy of leaf and stem, with a brief history of the subject, Vol I. $2^{\text {nd }}$ ed. Clarendon Press, Oxford.

Metcalfe, C. R. and L. Chalk. 1985. Anatomy of dicotyledons: Wood structure and conclusion of the general introduction, Vol II. $2^{\text {nd }}$ ed. Clarendon Press, Oxford.

Millán, B. and F. Kahn. 2010. Characterization of leaf anatomy in species of Astrocaryum and Hexopetion (Arecaceae). Revista Peruana de Biologia 17: 81-94.

Moraes, T. M. S., G. R. Rabelo, C. Alexandrino, S. J. S. Neto and M. Da Cunha. 2011. Comparative leaf anatomy and micromorphology of Psychotria species (Rubiaceae) from the Atlantic Rainforest. Acta Botanica Brasilica 25: 178-190.

Noorbakhsh, S. N., A. Ghahreman, F. Attar and K. Mahdigholi. 2008. Leaf anatomy of Artemisia (Asteraceae) in Iran and its taxonomic implications. Iranian Journal of Botany 14: 54-69.

Parkhurst, D. F. 1978. The adaptive significance of stomatal occurrence on one or both surfaces of leaves. Journal of Ecology 66: 367-383.

Potter, D., T. Eriksson, R. C. Evans, S. H. Oh, J. E. E. Smedmark, D. R. Morgan, M. Kerr, K. R. Robertson, M. P. Arsenault, T. A. Dickinson and C. S. Campbell. 2007. Phylogeny and classification of Rosaceae. Plant Systematics and Evolution 266: $5-43$.

Rahn, K. 1989. A survey of the genus Sorbaria (Rosaceae). Nor- 
dic Journal of Botany 8: 557-563.

Raven, P. H. 1963. A flora of San Clemente Island, California. Aliso 5: 289-347.

Ruzin, S. E. 1999. Plant microtechnique and microscopy. Oxford University Press, New York \& Oxford.

Rydberg, P. A. 1908. Rosaceae. In North American Flora, Vol. 22. Britton, N. L. and L. M. Underwood (eds.), New York Botanical Garden, New York. Pp. 239-292.

Schroeter, C. 1923. Das Pflanzenleben der Alpen. Eine Schilderung des Höchgebirgsflora. Alberta Ranstein, Zurich.

Schulze-Menz, G. K. 1964. Rosaceae. In Engler's Syllabus der Pflanzenfamilien II. Melchior. H. (ed.), $12^{\text {th }}$ ed. Gebrüder Borntraeger, Berlin. Pp. 209-218.

Skoss, J. D. 1955. Structure and composition of plant cuticle in relation to environmental factors and permeability. Botanical Gazette 117: 55-72.

Smith, W. K., T. C. Vogelmann, E. H. DeLucia, D. T. Bell and K. A. Shepherd. 1997. Leaf form and photosynthesis. Bioscience 47: 785-793.

Smith, W. K., D. T. Bell and K. A. Shepherd. 1998. Associations between leaf structure, orientation, and sunlight exposure in five Western Australian communities. American Journal of Botany 85: 56-63.

Solereder, H. 1908. Systematic anatomy of the dicotyledons, Vol . Clarendon Press, Oxford.

Song, J.-H., C. S. Chang and S.-P. Hong. 2010. First record of Sor- baria kirilowii (Rosaceae-Spiraeoideae) from Korea. Korean Journal of Plant Taxonomy 40: 174-178. (in Korean)

Song, J.-H. and S.-P. Hong. 2012. Comparative petiole anatomy in Forsythieae, Fontanesieae and Myxopyrum (Oleaceae) and its systematic implication. Korean Journal of Plant Taxonomy 42: 49-62. (in Korean)

Stuessy, F. T. 2008. Plant taxonomy: the systematic evaluation of comparative data. $2^{\text {nd }}$ ed. Columbia University Press, New York.

Takhtajan, A. 1997. Diversity and classification of flowering plants. Columbia University Press, New York.

Viguier R. 1906. Recherches anatomiques sur la classification des Araliacées. Annales des Sciences Naturelles. Botanique 4: 1210.

Wilkinson, H. P. 1979. The plant surface (mainly leaf). In Anatomy of the dicotyledons: Systematic anatomy of leaf and stem, with a brief history of the subject, Vol I. $2^{\text {nd }}$ ed. Metcalfe, C. R. and L. Chalk (eds.), Clarendon Press, Oxford.

Zhang, S. Y. 1992. Systematic wood anatomy of the Rosaceae. Blumea 37: 81-158.

Zhang, S. Y., P. Bass and M. Zandee. 1992. Wood structure of the Rosaceae in relation to ecology, habit and phenology. IAWA (International Association of Wood Anatomists) Bulletin 13: 307-349.

鏑木德二, 1940. 鮮滿實用林業便覽. 朝鮮總督府林業試驗場刊 行會, 養賢堂, 東京. (in Japanese) 


\section{Appendix: Specimens investigated. ( ${ }^{*}$ photographed for the leaf anatomy).}

Adenostoma fasciculatum Hook. \& Arn: USA, California, Los Angeles County, Santa Monica Canyon, 04. June. 1952. Anonymous 8707 (C); USA, California, San Mateo County, 12. June. 1941. L. S. Rose 14270 (GH)* - A. sparsifolium Torr.: USA, California, San Diego County, Laguna Mountain, 04. August. 1931. W. T. Swingle \& R. H. Peebles 323 (MO); USA, California, Riverside County, West of Keen Lake Camping, 21. August. 1935. I. W. Clokey, \& E. G. Anderson 6674 (MO); USA, California, Los Angeles County, Santa Monica Mountain, 20. November. 1932. B. D. Stark 4421 (A)* - Chamaebatiaria millefolium (Torr.) Maxim.: USA, California, Los Angeles County, Cory Canyon, 7. September. 1938. W. Andrew Archer 6977 (GH)*; USA, Utah, Juab County, Pinon Mountain, 20. June. 1933. B. Maguire 2646 (GH) - Lyonothamnus floribundus A.Gray subsp. floribundus: USA, California, Los Angeles County, Santa Catalina Island, 22. May. 1962. Peter H. Raven 17833 (GH)*; USA, California, Los Angeles County, Santa Catalina Island, 21. May. 1962. Peter H. Raven 17816 (GH) - L. floribundus A.Gray subsp. aspleniifolius (Greene) P.H. Raven: USA, California, Santa Clara County, Stanford University, 22. May. 1962. Anonymous s.n. (C); USA, California, Los Angeles County, Claremont, Rancho Santa Ana Botanic Garden, 20. June. 1971. J. Henrickson 5590 (GH)* - Sorbaria arborea C.K.Schneid. var. arborea: China, Shaanxi Province, Baoji City, 03. June. 2008. W. Jianyong SX 1439 (SNUA)* - S. arborea var. subtomentosa Rehder: China, Sichuan Province, 01. January. 1914. E. H. Wilson 2744 (K)* - S. grandiflora (Sweet) Maxim.: Russia, Buryatia, 01. August. 1964. V. N. Siplivinskij s.n. (K)* - S. kirilowii (Regel \& Tiling) Maxim.: Korea, Gyeonggi-do, Pocheon-si, 13. July. 2010. J. H. Song 10071301 (KHUS)*; Korea, Gyeonggi-do, Yangpyeonggun, Samgak Mountain, 7. June. 2010. J. H. Song 10060701 (KHUS); China, Shaanxi Province, Xi'an, Zhu Que Mountain, 29. June. 2008. J. I. Jeon SX1091 (KH) - S. pallasii (G.Don) Pojark.: Russia, Primorsky Krai, 14. July. 1980. I. B. Vyshin 3030 (A); Russia, Khabarovsk Krai, Ayano-Maysky District, Without date. S. Kharkevich s.n. (K)* - S. sorbifolia (L.) A.Braun var. sorbifolia: Canada, Quebec Province, Longueuil, 12. June. 1917. M. Victorin 4341 (A); Russia, Zabaykalsky Krai, Nertschinski Sawod, 16. July. 1977. N. Alianskaia s.n. (C)* - S. sorbifolia (L.) A.Braun var. stellipila Maxim. (1): Korea, Gangwon-do, Inje-gun, Jeombong Mountain, 11. August. 1979. T. B. Lee s.n. (SNUA)*; Korea, Gangwon-do, Pyeongchang-gun, Hwangbeong Mountain, 13. July. 1964. T. B. Lee s.n. (SNUA) - S. sorbifolia (L.) A.Braun var. stellipila Maxim. (2): Korea, Seoul, Seoul National University, 26. July. 2010. J. H. Song 10072601 (KHUS)*; Japan, Hokkaido, Kushiro Province, 04. September. 1965. N. Naruhashi 1147 (C) - S. sorbifolia (L.) A.Braun f. incerta (C.K.Schneid.) Kitag.: Unknown site, Unknown date. Anonymous s.n. (SNUA); Korea, Gyeonggi-do, Pocheon-si, Gwangneung, 18. June. 1986. S. S. Kim s.n. (KH)* - S. tomentosa (Lindl.) Rehder: Afghanistan, Wais Morah, Darrah Alis̄eng, 06. June. 1971. G. Wilson \& T. F. Hewer 1053 (K)*; Pakistan, Khyber Pakhtunkhwa Province, Swat District, 01. October. 1977. Muqarrab Shah \& Dilawar 357 (A) - Spiraeanthus schrenkianus (Fisch. \& C.A.Mey.) Maxim.: Kazakhstan, South Kazakhstan Province, Shymkent, Karatan Mountain, 10. June. 1982. I. I. Russanovich s.n. (A)*; Kazakhstan, Without locality, 05. September. 1976. O. Knorring s.n. (C). 